\title{
Advancing the views on migrant and diaspora entrepreneurs in international entrepreneurship
}

\author{
Maria Elo ${ }^{1,2,3} \cdot$ Susanne Sandberg $^{4} \cdot$ Per Servais $^{4}$. \\ Rodrigo Basco ${ }^{5}$ - Allan Discua $\mathrm{Cruz}^{6}$. \\ Liesl Riddle $^{7} \cdot$ Florian Täube $^{8,9}$
}

Published online: 30 May 2018

(C) The Author(s) 2018

\section{Introduction}

We start challenging the basis of what constitutes the international and the entrepreneur in international entrepreneurship (IE) by relating international entrepreneurship to migration, migrants and diasporas, and their transnational and international ventures as dimensions rarely studied. This discussion focusing on the individual, human levelbeyond the entrepreneurship-firm level — brings the actor and agency dimensions in the forefront of business activity regarding international entrepreneurship. There is a myriad of theoretical and analytical challenges in the literature in studying migrants that start from ambiguous terms and definitions and continue to different national systems of assessing and reporting migrantness. Such complexity generates cases of entrepreneurs who are not within any mainstream categories, highlighting a lack of appropriate definitions and working criteria. There is no consensus on the inclusion of

Maria Elo

maria.elo@utu.fi

1 School of Economics, Belt \& Road Institute of International Business, Shanghai University, Shanghai, China

2 Turku School of Economics, University of Turku, Turku, Finland

3 Migration Institute of Finland, Turku, Finland

4 Linnaeus University, Kalmar, Sweden

5 American University of Sharjah, Sharjah, United Arab Emirates

6 Lancaster University, Bailrigg, UK

7 The George Washington University, Washington, DC, USA

8 European Management School, Mainz, Germany

9 Université libre de Bruxelles, Brussels, Belgium 
migrant entrepreneurs and their position in international entrepreneurship, as views differ between partial inclusions; "Diasporans who establish new ventures in their countries of origin comprise a special case of international ethnic entrepreneurship" (Riddle and Brinkerhoff 2011, 670) and partial exclusion; "we exclude studies on transnational, ethnic and immigrant entrepreneurship from this review. This follows Drori et al. $(2009,1003)$ who observe that while in principle, transnational entrepreneurship is fundamentally compatible with IEs entrepreneurial initiative the approach and domain differ markedly from IE"" (Jones et al. 2011, 644).

Conceptualizing the "international entrepreneur" in IE is a fundamental issue for theory development and provokes debates since the "who" question already contested early on in entrepreneurship research (cf. Gartner 1989) remains challenging regarding definitions, analysis, and theoretical foundations. The mobility turn, international migration, and globalization (Castles 2010; Faist 2013; Vertovec 2004) have challenged the border concepts and their meanings and the blurred perceived distinction between national and international contexts, which makes older rigid frameworks unsuitable for approaching the phenomenon. Consequently, the processes of entrepreneurial internationalization have evolved to address and accommodate new aspects. These real-life aspects require that context and the respective entrepreneur-participants need novel and deeper attention, for example, regarding respective preconditions, sequences, paths, and behaviors (cf. Drori et al. 2009; Elo 2016). Behavioral schemes are evolving and international opportunities are addressed, perceived, and generated differently than those in some decades ago, even on more aggregated levels influencing institutions and systems (Brinkerhoff 2016).

Therefore, while broadening the debates abovementioned, one aim of this special issue is to enlarge and enrich the debates and deepen our understanding on IE and inherent diverse actors operating in its field. For instance, contemporary challenges in addressing the entrepreneur-person level include the types of individuals and their respective contexts that have not been previously perceived within international entrepreneurship, for example, refugees who act in international business as entrepreneurs (cf Sandberg et al. 2017). Further, the second aim is to contribute to the field of IE by exploring whether, how, and why the IE activities of migrant and diaspora entrepreneurs differ from other internationally oriented entrepreneurs, and how this international element in these entrepreneurs' lives is particular and meaningful for their entrepreneurial development (Etemad 2016; Jones et al. 2011; Jones and Coviello 2005). In terms of paths and processes of internationalization and international business, migrant and diaspora entrepreneurs illustrate different, even unusual, pathways in their entrepreneurial internationalization (EI) as they possess particular capabilities for bridging international contexts (Riddle et al. 2010).

There is much potential for better understanding of the geography of entrepreneurial internationalization processes when a deeper analysis on the actors is applied. The capabilities and dynamics related to migrants and diasporans and their migratory paths may benefit from an explanation of respective EI, their market selection, entry modes, business operations and models, international diffusion of products and ideas, as well as service development. In the sense of classic international business, the internationality is often reflected with nation state division, through home and host country concepts, making the focal dyad and cross-border lens rather dominant (Chung et al. 2012; Jones et al. 2011; Mainela et al. 2014; Nkongolo-Bakenda and Chrysostome 2013), while the 
transnational and multifocal approaches are emerging and providing views beyond the dyadic scheme (Solano 2016; Terjesen and Elam 2009). Markedly, these diverse international entrepreneurial activities may involve inward and outward internationalization, as well as cooperative arrangements, leaving more room for understanding directions (Welch and Luostarinen 1993).

Implicitly, we also contest the idea of the "mono-view," the pre-labeled and too narrow lenses and research approaches commonly employed when studying migrant and diaspora entrepreneurs, as often these stem from copy-paste of approaches from other disciplinary fields, such as sociology or racial studies. Interestingly, migrants and diasporans are commonly seen as having a deficit-necessity position in a society and as entrepreneurs, but at the same time, they may mobilize diverse resources that foster business development and support internationalization processes, which may happen transnationally linking home and host contexts (Discua Cruz et al. 2013; Drori et al. 2009; Elo and Volovelsky 2017; Emontspool and Servais 2017; Jones and Coviello 2005; Terjesen and Elam 2009; Turunen and Nummela 2016). In the international human resources and expatriation literature, the resources of migrants and diasporans are addressed as even superior for international business, and seen as particular assets (e.g., Mahroum 2000; Vance et al. 2016; Tung 2008). Positive aspects, such as opportunities and international capabilities, can also be crucial in explaining their entrepreneurship (Discua Cruz et al. 2012; Elo et al. 2015; Mainela et al. 2014; Nijkamp et al. 2010). In short, migrant and diaspora entrepreneurs face additional complexities and richness that relate to their business environments and contexts, ethnicities, resources and business models, regimes, and borders, but also to their transnationalism and "in-betweenness," but these complexities may generate advantages and development as a result (Brinkerhoff 2016; Etemad 2017a). Empirical research on such particular capabilities in coping with impediments and demanding settings, as well as on how these capabilities influence entrepreneurial internationalization emerge and illustrate the particular nature of these capabilities and advantages (Bai et al. 2016; Rana and Elo 2017). Moreover, diasporans are often particularly entrepreneurial and therefore, learning from their successful entrepreneurship can have instrumental value (Basu and Virick 2015; Brinkerhoff 2016).

Migrants and diaspora entrepreneurs are also subjects to plurality of social, cultural, religious, and organizational settings and have various roles and positions as entrepreneurs, intrapreneurs, family business owners and managers, business owners and managers, venture capitalists, and change makers (e.g., Elo and Riddle 2016). Social networks, social capital, and social embeddedness, together with family dynamics, long-term intentions, and even succession paths that foster IE provide fruitful angles of addressing migrant and diaspora businesses (e.g., Howorth et al. 2010). It is known that families, clans, ethnic communities, and global diasporas influence these types of entrepreneurs and their operations; moreover, there can be several generations of migrant families in business and transnational diaspora ecosystems that shape the economic development and business environment (e.g., Discua Cruz et al. 2013; Discua Cruz and Basc 2017; Minto-Coy and Elo 2017). Also in transnational entrepreneurship, networks and in particular their social networks have been considered crucial and the lens of glocalized networks - networks that have both local and global connections - have been seen most suitable in examining entrepreneurial activity across borders (Chen and Tan 2009).

This special issue addresses these differences, the "otherness" of migrants and diasporans as international entrepreneurs and conduits for internationalization from 
multiple angles bringing new empirical insights into the research on entrepreneurship, reflecting both liabilities and assets as well as the positions in relation to minoritymajority constellations (Johanson and Vahlne 2009; Rath and Kloosterman 2000). It contributes by discussing the concept of the "entrepreneur and embedded-self" in terms of the entrepreneur-individual and her/his process over time and place (Kloosterman and Rath 2001; Price and Chacko 2009), and by providing novel dimensions for theoretical and analytical discussions.

There are numerous ongoing debates regarding contextualization and the need for further contextualization to address international and transnational business in academia (Aggarwal and Goodell 2015; Ambrosini 2012; Welter 2011). Embeddedness in a particular context, and terms such as contextual, situational, and contingency stand as a diachronic concern for research (cf. Tung, 2018). In social and cultural studies, for example, the role of context and the respective embeddedness of the actor researched has been in the epicenter of research attention since Granovetter's work in the early 1970s (Granovetter 1985a, 1985b; Granovetter 1973; Urbano et al. 2011). Embeddedness has been essential in understanding internationalization, business networks, and organizational studies (Coviello 2006; Ghoshal and Bartlett 1990; Johanson and Mattsson 2015). Particularly, in research on immigrants, migrants and diasporans, and their entrepreneurship, their complex contextual setting needs highlighting and relates to the arena of their focal activity (cf. Zahra et al. 2014). The role of embeddedness and mixed embeddedness of migrant origin entrepreneurs makes them different from native and local entrepreneurs who do not have these additional layers of contextual embeddedness (Elo 2016; Jones et al. 2014; Kloosterman 2010; Kloosterman and Rath 2001; Price and Chacko 2009; Ram et al. 2008; Rath and Kloosterman 2000; Terjesen and Elam 2009). In addition, international business and entrepreneurship literature and conferences, such as the McGill International Entrepreneurship (MIE) and the European International Business Academy (EIBA) conferences, are increasingly discussing and incorporating the meaning of the context when analyzing a particular activity of a firm or an entrepreneur (Marschan-Piekkari and Welch 2004; Zahra et al. 2014). In short, these research approach-related developments confirm the importance of deeper insights and more holistic lenses.

This special issue provides novel perspectives in the context of IE that contest the views on developed vs. developing or emerging economies. Therefore, it also underlines the meanings of geography, politics, and relations between populations that influence international entrepreneurship (Nijkamp et al. 2010; Sheffer 2003; Tölölyan 2007; Wright and Ellis 2016). The special issue brings insights from post-conflict economies and from social settings that are unusual and have not been in the radar of IE research previously. However, we believe that geographic, political, social, cultural, and religious contexts require more research attention, particularly in this contemporary setting. For example, there is an increasing level of ambiguity and uncertainty in the global entrepreneurial context, and at the same time, the growth potential is significant in less well-known areas or configurations (Hill and Mudambi 2010; Kotabe and Mudambi 2009; Powell and Steel 2011). An advancement of "glocal" and transnational understanding in IE may be helpful in addressing the increasing complexity, and for this, multiple perspectives and disciplinary lenses are required (Etemad 2017a).

We wish to foster debates for future scholarly work and co-develop a broader view of IE with this special issue (Etemad 2017a). 


\section{Framing migrant and diaspora entrepreneurs in international entrepreneurship}

There are ongoing discussions regarding the ways how international entrepreneurship is conceptualized and contextualized and what kind of foundation these discussions employ, which refer to the framing of the respective research questions (Etemad 2017a, 2017b; Welter 2011; Zahra et al. 2014). International entrepreneurship has invested a lot of attention in the firm and its expansion and the respective entrepreneur while the individual as the entrepreneur-venture establisher has gained much more attention in sociology and related fields of inquiry. The early discussions addressing the entrepreneur as the primus motor need revival when framing migrant and diaspora entrepreneurs as active international entrepreneurs, due to their different resources, contexts, and embeddedness (Masurel et al. 2002; Oviatt and McDougall 2005). International social constellations, even marriages, prove relevant for entrepreneurial dynamics and opportunities. These form not just constraints, but also potential and systems for resources and networks. In addition to economic and political networks, especially, social networks can be highly influential and glocal connecting the entrepreneur both on local and global level (Chen and Tan 2009).

The stream of research adopting views from transnationalism, introducing transnational entrepreneurship has been a ground-breaking change in terms of adding to the view via a more positive lens (cf. positive organizational scholarship, POS) on migrants as entrepreneurs (Stahl and Tung 2015). Prior works, particularly in sociology, approach entrepreneurship and business venturing with a deficit lens, often with a necessity and economic adaptation focus. This suggests that the entrepreneurs have difficulties, even less capabilities and resources to cope with the business environment than the locals and that they are subjects to assimilation (cf. Chen and Tan 2009). Transnational entrepreneurship and transnational diaspora entrepreneurship literatures were the first approaches that started with a different ontological standpoint in which transnational migrants and diasporans would have additional and different competitive advantages and resources compared to the locals (Dai and Liu 2009; Gillespie et al. 1999; Rana and Elo 2017; Riddle and Brinkerhoff 2011; Riddle et al. 2010; Stahl and Tung 2015). The interplay of deficit vs. positive organization scholarship lens has long tended to shift on the negative while the opposite is advocated in international business studies (Stahl and Tung 2015). For a more balanced view, this special issue has framed both sides of the token, multiple layers, and through multiple disciplinary perspectives.

Building on the papers of this special issue and the ongoing discussions, we illustrate the disciplinary lenses that are incorporated in explaining migrant and diaspora entrepreneurship as a schematic representation in line with Etemad (2017a, 2017b) conceptual multi-layered framework of international entrepreneurship. Etemad's framework illustrates the international entrepreneurship domain at the common intersection of five selected influential disciplines; these are entrepreneurship, international business, networks, strategy, and operations management (Etemad 2017a). Diasporas and migrants operate on these and on additional layers of international entrepreneurship enriching the domain (Fig. 1). 


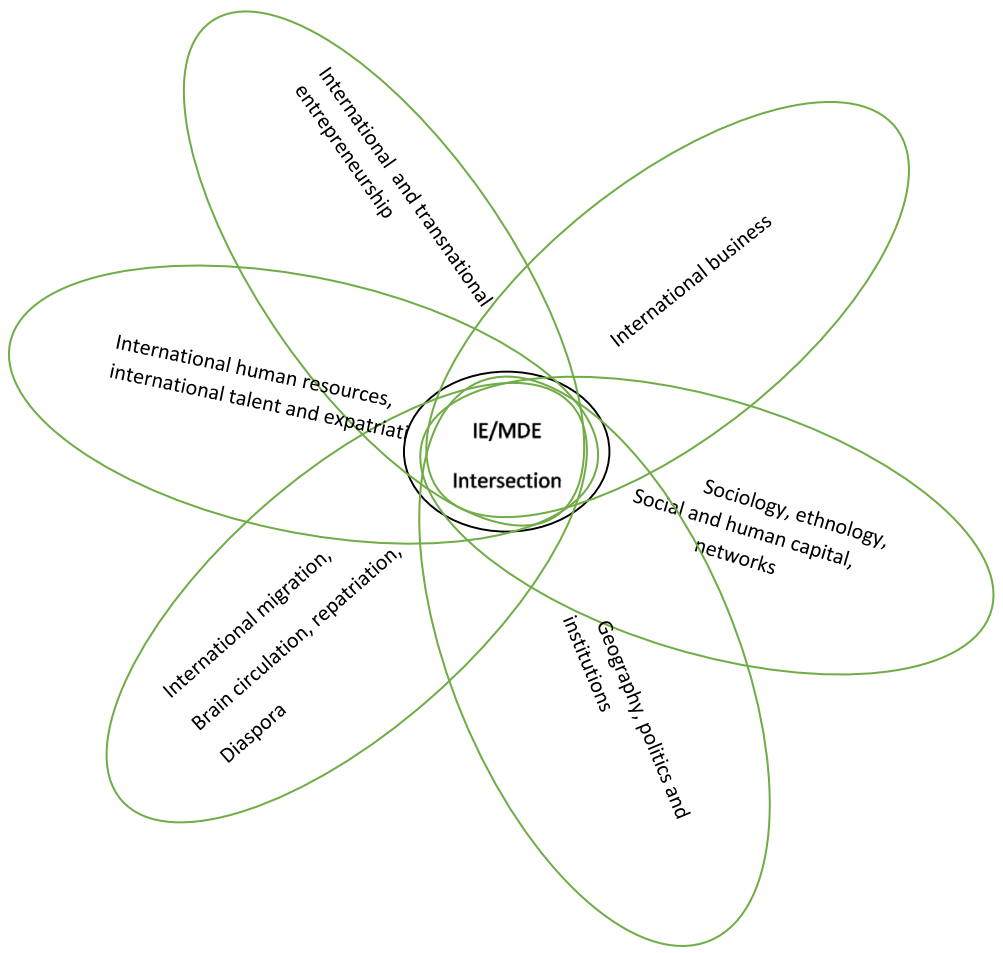

Fig. 1 Multiple and interdisciplinary lenses employed in understanding and explaining migrant and diaspora entrepreneurship (MDE) - a schematic representation on the overlaps adopted and modified from Etemad (2017a: 234)

\section{Introducing different perspectives-A contribution of the special issue}

This special issue provides novel theoretical and empirical perspectives to the debate about migrant and diaspora in international entrepreneurship. Each article brings a unique viewpoint to frame the discussion on the phenomenon under study and come to unique empirical evidence through different contexts. The following section introduces the articles of this special issue. We start with the discussion on entrepreneurial types and expatriation and continue with transnational venturing in a distant host context; both articles provide a rather positive angle on talent and opportunity. The third article shifts the focus and builds on the "liability of ethnicity" and entrepreneur heterogeneity in the host context addressing the differences between native and immigrant entrepreneurs in exports. The fourth one examines influences of motivation and ethnic ties but focuses on entry of transnational ventures in the old home country, providing the opposite view to the "outward" logic. The fifth article continues the transnational focus and examines transnational post-conflict entrepreneurship in host-home context. The sixth article examines discrimination and subjective wellbeing of Latino migrant entrepreneurs in the USA and suggests that transnational entrepreneurs perceive host country differently and more critically. Finally, the last article ends the discussion with the most negative constellation, a critical case of entrepreneurship, where the entrepreneurship is a result of a conflict in home country and takes place in host country overcoming difficulties with host country-located social capital. 


\section{Who is an expat-preneur? toward a better understanding of a key talent sector supporting international entrepreneurship by Selmer, McNulty, Lauring, and Vance}

As this study of Selmer, McNulty, Lauring, and Vance indicates, modern mobility has many forms that require more attention. For example, expatriate status is traditionally seen as a corporate career phase that is a building block toward top management. However, in the era of globalization, self-initiated expatriates (SIE) have become more and increasingly important also as entrepreneurs (Habti and Elo in press). Selmer et al. reflect the discussion on expat-preneurs and the meaning of this category with the international entrepreneurship domain. They advance the views on the person, particularly on the personal migration background, demographic features, and entrepreneurial activity and provide an alternative angle to address entrepreneurs who act in international contexts. Their study surveys SIEs with entrepreneurial business operations and in employment and compares the two groups in three contexts: China, Hong Kong, and Singapore, all of which are places of intensive international business and strong inflows of global talent. They find that expat-preneurs and employed corporate expats differ mainly in their age, position, time spend in the place/context in the current job, their time, or "career," as an expatriate in the host context, but did not find differences in gender, educational level, or in marital status.

\section{Transnational entrepreneurship: Opportunity identification and venture creation by Lundberg and Rehnfors}

The paper co-authored by Lundberg and Rehnfors focuses on transnational entrepreneurship and on the specific phenomenon of immigrant entrepreneurship. The authors go beyond the traditional research, which investigates immigrants moving from lessdeveloped countries to developed ones and being driven by necessity opportunities, in order to explore the contemporary process of opportunity identification among seven transnational entrepreneurs who moved from developed counties to Hong Kong. This study shows the importance of individual characteristics, type of firms created, and the institutional and cultural context as dimensions affecting the process of opportunity identification. Even though the authors found general evidence described in three levels of analysis (individual, firm, and context) to study immigrant entrepreneurship, this line of research has to be further developed in order to systematize these dimensions and their components and to explain how these dimensions collide in the entrepreneur who aims to discover and exploit new opportunities when moving between developed countries or developed regions. Additionally, future studies should disentangle the difference and similarities in the aforementioned level of analysis between immigrant entrepreneurship moving from developing to developed, from developed to developing countries, and between developed countries.

\section{Evaluations of export feasibility by immigrant and non-immigrant entrepreneurs in new technology-based firms by Bolzani and Boari}

Bolzani and Boari explore the exciting phenomenon of immigrant-owned ventures' "liability of ethnicity" by investigating whether and how one relevant source of 
entrepreneur heterogeneity, i.e., migrant condition, impacts the perceived feasibility of exporting opportunities. Drawing on a sample of 71 immigrants and 69 native entrepreneurs active in non-internationalized new technology-based firms in Italy, they find that the migrant condition positively moderates the relationship between perceived public financial support and perceived feasibility of exporting, whereas it negatively moderates the relationship between international business skills and perceived export feasibility.

\section{Ethnic ties, motivations and home country entry strategy of transnational entrepreneurs by Pruthi, Basu, and Wright}

The paper co-authored by Pruthi, Basu, and Wright "Ethnic ties, motivations, and home country entry strategy of transnational entrepreneurs" nicely complements the other papers in this special issue through a matched-sample methodology of 30 interviews with Indian transnational entrepreneurs in the USA and their corresponding India heads of operation. It contributes with an extension of the theoretical and empirical literature on the motivations of transnational entrepreneurship by showing a heterogeneity of both TE's motivations, in terms of economic and emotional motivations, and their home country entry strategy, in terms of proactive and reactive strategies. Furthermore, they find that TE's entry strategy depends on (a) use of professional and personal ethnic ties and (b) prior experience of doing business with the home country. They also extend the migrant entrepreneurship literature by exploring the role of ethnic professional, and family and non-family ties in venture founding in the host and home countries, and demonstrating the heterogeneity in how TEs use these ties to simultaneously launch a new, rather than grow an existing, venture in the two countries.

\section{Fragmented networks and transnational entrepreneurship: Building strategies to succeed in challenging surroundings by Muñoz, Alvarez, Sarmiento, and Zapata}

Very often, network connection is seen as open and inviting. The article by Muñoz, Alvarez, Sarmiento, and Zapata takes another stand, as it focusses on the attributes of transnational entrepreneurs with small and fragmented networks, from post-conflict environments. These entrepreneurs can perform an important role in the socioeconomic development and internationalization level of their countries of origin due to the crossborder mobilization of resources they encourage. Muñoz et al. look at the specific case of Colombian transnational entrepreneurs who have been able to overcome those obstacles. Their transnational business is analyzed with the intention of understanding how they manage those shortcomings when engaging in transnational entrepreneurship. The article underlines the meaning of the entrepreneurs' networks and entrepreneurial strategy in generating business success.

\section{Shaping the castle according to the rocks in the path? Perceived discrimination, social differences, and subjective wellbeing as determinants of firm type among immigrant entrepreneurs by Poblete}

Poblete contributes with a focus on the drivers of transnationalism while comparing domestic-based and transnational Latino immigrant entrepreneurs in the USA. The 
Latino population, here represented by Colombians, Dominicans, and Salvadorans, has been a large immigrant group since the 1990s, and even though the current situation in the USA is changing, the findings remain potentially accurate across time. Taking a departure from institutional theory, the author argues that transnational entrepreneurs are characterized in terms of their differing perceptions of the host society in comparison to conventional immigrant entrepreneurs. Testing three aspects of individuals' perception of informal institutions, namely, (1) individuals' perception of discrimination based on first-person and third-person experience, (2) individuals' perception of social differences, and (3) subjective wellbeing, it is shown that transnational entrepreneurs are more likely to perceive social differences within the host society, to have been discriminated against, and to experience dissatisfaction regarding opportunities and income. Contributions cover identification of three informal institutions as drivers of transnationalism in comparison to domestic-based immigrant entrepreneurs.

\section{Coming out of conflict: How migrant entrepreneurs utilize human and social capital by Williams and Krasniqi}

While conflict-related migration has occurred for centuries, it is only recently that scholars are paying close attention to how such phenomenon influences entrepreneurship (e.g., Nielsen and Riddle 2010). Conflictive areas are often flagged as contexts plagued by war, persecution, political instability, and socioeconomic crises. Under such conditions, migrants are often forced to leave their homeland with limited or no resources. Migrants may be constrained in the options for economic activity once they arrive into their new countries of residence. This article advances our understanding by examining how human and social capital influences the entrepreneurial activity of migrant entrepreneurs, with particular attention to forced migration due to conflict. Williams and Krasniqi study describes the major issues and considerations migrant entrepreneurs must address when engaging in entrepreneurial activities in their host countries. The study shows that migrant entrepreneurs leverage what they learn in their host societies in terms of education and skills as well as nurturing networks as critical to engage into entrepreneurship. Their findings reveal that mastery of the local language, marriage with local members of the community, and the subsequent buildup of networks in host societies have an impact on migrant entrepreneurship. A relationalbased advantage can be expected in migrants married to a native of the country of residence based on information access, networks, and context embeddedness.

\section{An open discussion and concluding remarks}

The theoretical discussions highlight not only the diversity of approaches, analytical foci, forces, and mechanisms, but also different country and business contexts and resource types. To foster the debate, we have also collected views from the authors who are very diverse in their background in terms of country origin, gender, age, and discipline. As a result, their unfiltered views and those of the guest editors complement each other. Authors' responses to the question, "what do you think are the key takeaways regarding your submitted paper for our IE audience," triggered various views for a further discussion (responses in italics). These are their responses: 
- Perceptions of environmental- and individual-level factors that influence the intentions to export are "in the eye of the beholder" and therefore influenced by entrepreneurs' heterogeneous experiences. The migration condition is one of these experiences, and therefore we see that there are perceptual differences between migrant and non-migrant entrepreneurs with regard to the antecedents to the intentions to export.

- That IE is not just about companies, but about individuals.

- Need for opening-up the IE box.

- Introducing expatriation to the entrepreneurship field.

- Need to address the gap in empirical studies about expat-preneurs as an important, albeit under-researched, segment of the immigrant entrepreneur, and self-initiated expatriate diaspora.

- Host networking (foreign spouse and foreign migration experience has a positive impact on the probability of entrepreneurship and is influenced by human and social capital accumulation. Exposure to host country (both measured as years in migration and age) increases probability to start a business.

These viewpoints are interesting especially given that only two authors identified themselves as "classic international entrepreneurship scholars," while all others see themselves as having mixed or other disciplinary background. ${ }^{1}$ The backgrounds vary from international human resources, international business and marketing to more sociological and political angles. This multi- and interdisciplinary challenge is interesting and vital for triggering theoretical progress and cross-dissemination. For example, the ongoing discussion on expat-preneurs is very relevant to IE facing multiple similarities despite different perspectives (Vance et al. 2017, 2016). Such overlaps suggests synergies and potential for novelty in inclusive approaches and illustrate implicit conceptual continuums.

Among the key impediments the authors consider for international entrepreneurship research regarding migrants and diasporans included theory- and domain-specific comments, such as "I think that unfortunately this domain is characterized by a dearth of high-quality empirical materials; for example many low-quality qualitative research (in particular case studies). In addition, I see the risk of over-emphasizing the "ethnic" dimension, comparative studies should be more important", and "What is needed is more common views of the research and literatures of expatriates, migrants and diasporas. From terminologies to methodologies", but also methodological and practical concerns such as "Access to respondents" and "the founding team composition". We also investigated what aspects they perceive as crucial for the future discussions in international entrepreneurship and these provided stimuli for following issues: "Cognition and decision-making, in particular how do heterogeneity in entrepreneurs and their different experiences drive their decisions in the international domain? How does experience impact world views in entrepreneurs? How do they narrate their experience? Social international entrepreneurship: how do social entrepreneurs navigate different institutional environments?", "Commonalities and differences of distinct

\footnotetext{
${ }^{1}$ Notice, not all authors responded our questionnaire and due to technicalities, one author did not receive the questionnaire.
} 
diasporas," "How forced migration influences entrepreneurial activity, both during conflict and after," and "The difference between an INV and IE."

In a migratory sense, this special issue brought to light the heterogeneity in the diasporic processes around the world. One is the temporary migration, i.e., more short-term movements of entrepreneurs. The other, more enduring movement is the conflict-influenced diaspora which is a phenomenon that deserves further attention from diverse theoretical perspectives. In light of current world events, where people are increasingly displaced due to conflict in their homelands, migrant entrepreneurship provides a distinctive lens to understand how displaced migrants contribute to the entrepreneurial dynamics not only in their countries of residence but also in their country of origin post conflict.

These viewpoints underline the need for further theory discussion. We asked authors which are the hot topics and they identified: "Return migrant entrepreneurs, Social international entrepreneurs, International mobility of knowledge-also in form of entrepreneurship, cultural intelligence," "Forced migration; return migration to post-conflict economies, Expat-preneurs," and "Multi-Generational issues". We find that there is future potential in reflecting theoretical approaches and overlaps across traditional boundaries and disciplinary silos for more innovative and openminded examination, cross-dissemination, and synergies (cf. Etemad 2004, 2017a; Wiklund et al. 2011).

Managerially, there are numerous implications addressing the resource base and differences of migrants and diasporans as entrepreneurs and business actors in comparison to natives and locals. More research on families, clans, networks, and contexts may provide fruitful dimensions for addressing the processes related to IE and EI and assist in generating supplementary but significant knowledge.

Implications regarding policy making contribute also to fields beyond entrepreneurship and refer to migration and integration policies as well as societal balances, development, and opportunities (Brinkerhoff 2016; Newland and Tanaka 2010). Notably, formal institutional aspects and other societal institutions, such as marriage, become novel attention as part of the forces influencing entrepreneurship (Etemad 2014; Urbano et al. 2011; Vertovec 2004).

Methodological issues have long been an inherent difficulty in this sensitive domain connecting various disciplines, and this links to problems noted by authors, such as "Unit of analysis - the founder? The INV? The opportunities chased?", also "undertaking surveys," but again the difficulties are seen in the overall level noting "Terminology, definitions, boundary conditions of the constructs we say we are researching." One author suggests; "As already pointed out in previous response, very often studies use weak research design and empirical methodologies. One of the difficulties that I have personally found relevant at the theoretical level is whether this should only be considered a context where we study particular nuances of a theory (e.g., treating migrant status as boundary/moderating condition) or whether this is a field of research "per se." The interdisciplinary and multi-layered nature of IE constitutes an inclusion challenge, but also an opportunity for development.

Regarding research approaches, this special issue attempts to break the traditional mind-set corset that already exists in the field of international entrepreneurship. This corset has been made by the natural evolution of the field, which not only creates new knowledge to interpret, understand, and predict the phenomenon of international entrepreneurship, but also the knowledge boundaries. The knowledge boundaries are often based on a particular influence group that decides who is in or who is out in terms 
of science. Our intention is to expand the boundaries through a multidisciplinary approach to study the international entrepreneurship phenomenon by using different perspectives, new points of view, and alternative ways of framing article, adding new topics, and bringing new terms into the research arena.

Next-generation IE and EI research can benefit from its diversity and richness providing numerous lines of inquiry starting from context to theoretical angles. For example, further research can examine the diverse forms of post-conflict entrepreneurial engagement that is carried out and the associated repercussions such engagement have at different levels. Further research may elucidate the contributions by focusing on different units of analysis: individual, collective, or firm as well as the transformation of entrepreneurial capital that migrants experienced and that can be leveraged in their post-conflict home countries.

One alternative way to move the link between migrant/diaspora entrepreneurship and international entrepreneurship is to relate it to regional development from the home and host country perspectives. What the macro-impact of the migrant/diaspora may be in international entrepreneurship is a central question to explore. This will require an effort to shift the academic conversation from a micro perspective based on the immediate effect of migrant/diaspora entrepreneurship in topics such as, family economic and social effect to the local and regional economy and to a macro vision. In other words, there are two research questions: How are migrant and diasporic international entrepreneurs connected to economic and social development? and What are the regional productive mechanisms that international entrepreneurship of migrants/diasporas create, alter, or modify? One possible path to address this line of research inquiry is to use the "regional familiness model" (Basco 2015), which suggests the existence of two channels. The micro-channel in the relationship between family firms (international entrepreneurship migrants/diasporas) and regional development comes from the role family firms (international entrepreneurship migrants/ diasporas) play in creating, transforming, and allocating resources (i.e., productive factors, human capital, social capital, and creative/entrepreneurial capital). Second, the macrochannel by considering the effects of proximity on regional processes (such as spillovers, information exchange, learning processes, social interactions, and competition and institutional dynamics) that can accelerate or slow the endogenous and exogenous factors that contribute to external agglomeration effects (i.e., those economies of scale that go beyond individual agents and depend on the collective action of agents).

Finally, we recognize the challenges that the complexity, multidisciplinary nature, and multi-layered analysis may generate, but consider these from the positive organizational scholarship lens as something that adds to the richness of the IE's body of knowledge. We consider that shifting from rigid frames to broader and deeper understanding contributes to both theory advancement and domain development per se. Starting from the definitions, there is room for addressing conceptual commonalities, elements, and mechanisms, and providing advances for more and better contextualized studies. As a conclusion, we suggest that the movement, the mobility of people, firms, and business activities, and the plurality of these origins and origin constellations - in the context between borders and borderlessness - set the dynamics for the next research agenda for EI and IE.

Acknowledgements We would like to thank the George Washington University's Center for International Business Education and Research (http://business.gwu.edu/research.ciber) for providing financial support to enable this paper to be available via open access. 
Open Access This article is distributed under the terms of the Creative Commons Attribution 4.0 International License (http://creativecommons.org/licenses/by/4.0/), which permits unrestricted use, distribution, and reproduction in any medium, provided you give appropriate credit to the original author(s) and the source, provide a link to the Creative Commons license, and indicate if changes were made.

\section{References}

Aggarwal R, Goodell JW (2015) Contextual richness in teaching IB: ethics, language, and social factors. J Teach Int Bus 26(2):77-80. https://doi.org/10.1080/08975930.2015.1056714

Ambrosini M (2012) Migrants' entrepreneurship in transnational social fields: research in the Italian context. Int Rev Sociol 22(2):273-292. https://doi.org/10.1080/03906701.2012.696970

Bai W, Holmström Lind C, Johanson M (2016) The performance of international returnee ventures: the role of networking capability and the usefulness of international business knowledge. Entrep Reg Dev 28(9-10): 657-680. https://doi.org/10.1080/08985626.2016.1234003

Basu A, Virick M (2015) Silicon Valley's Indian diaspora: networking and entrepreneurial success. South Asian J Glob Bus Res 4(2):190-208. https://doi.org/10.1108/SAJGBR-04-2014-0021

Brinkerhoff JM (2016) Defining entrepreneurs and exploring diaspora applications. In Institutional reform and diaspora entrepreneurs : the in-between advantage D exploring (pp. 1-38). https://doi.org/10.1093/acprof

Castles S (2010) Understanding global migration: a social transformation perspective. J Ethn Migr Stud 36(10):1565-1586. https://doi.org/10.1080/1369183X.2010.489381

Chen W, Tan J (2009) Understanding transnational entrepreneurship through a network lens: theoretical and methodological considerations. Entrep Theory Pract 33(5):1079-1091. https://doi.org/10.1111/j.15406520.2009.00335.x

Chung HFL, Rose E, Huang P h (2012) Linking international adaptation strategy, immigrant effect, and performance: the case of home-host and cross-market scenario. Int Bus Rev 21(1):40-58. https://doi.org/10.1016/j.ibusrev.2010.11.001

Coviello N (2006) The network dynamics of international new ventures. J Int Bus Stud 37(5):713-731. https://doi.org/10.1057/palgrave.jibs.8400219

Dai O, Liu X (2009) Returnee entrepreneurs and firm performance in Chinese high-technology industries. Int Bus Rev 18(4):373-386. https://doi.org/10.1016/j.ibusrev.2009.03.004

Discua Cruz A, Hamilton E, Jack SL (2012) Understanding entrepreneurial cultures in family businesses: a study of family entrepreneurial teams in Honduras. J Fam Bus Strat 3(3):147-161. https://doi.org/10.1016 j.j.jbs.2012.05.002

Discua Cruz A, Howorth C, Hamilton E (2013) Intrafamily entrepreneurship: the formation and membership of family entrepreneurial teams. Enterp Theory Pract 37(1):17-46. https://doi.org/10.1111/j.15406520.2012.00534.x

Drori I, Honig B, Wright M (2009) Transnational entrepreneurship: an emergent field of study. Enterp Theory Pract 33(5):1001-1022. https://doi.org/10.1111/j.1540-6520.2009.00332.x

Elo M (2016) Typology of diaspora entrepreneurship: case studies in Uzbekistan. J Int Entrep 14(1):121-155. https://doi.org/10.1007/s10843-016-0177-9

Elo M, Volovelsky EK (2017) Jewish diaspora entrepreneurs - the impact of religion on opportunity exploration and exploitation. Int J Entrep Small Bus 31(2):244. https://doi.org/10.1504/IJESB.2017.084090

Elo M, Harima A, and Freiling J (2015) To try or not to try a story of diaspora entrepreneurship. Prog Int Bus Res (Vol. 10). https://doi.org/10.1108/S1745-886220150000010015

Emontspool J, Servais P (2017) Cross-border entrepreneurship in a global world: a critical reconceptualisation. Eur J Int Manage 11(3):262-279. https://doi.org/10.1504/EJIM.2017.083875

Etemad H (2004) International entrepreneurship in small and medium size enterprises: orientation, environment and strategy. 1-276. doi:https://doi.org/10.4337/9781845421557.00001

Etemad H (2014) The institutional environment and international entrepreneurship interactions. J Int Entrep 12(4):309-313. https://doi.org/10.1007/s10843-014-0140-6

Etemad H (2016) International entrepreneurship as a young field of scholarly inquiry and its relationship with the knowledge network of five related disciplines. J Int Entrep 14(2):157-167. https://doi.org/10.1007 /s10843-016-0180-1

Etemad H (2017a) Towards a conceptual multilayered framework of international entrepreneurship. J Int Entrep 15(3):229-238. https://doi.org/10.1007/s10843-017-0212-5 
Etemad H (2017b) Towards an emerging evolutionary life-cycle theory of internationalized entrepreneurial firms: from born globals to borderless firms? J Int Entrep 15(2):111-120. https://doi.org/10.1007/s10843017-0204-5

Faist T (2013) The mobility turn: a new paradigm for the social sciences? Ethnic Racial Stud 36:1637-1646. https://oi.org/10.1080/01419870.2013.812229

Gartner WB (1989) "Who is an entrepreneur?" is the wrong question. Am J Small Bus 89:1010-1013. https://doi.org/10.1210/jc.2003-031037

Ghoshal S, Bartlett CA (1990) The multinational corporation as an interorganizational network. Acad Manag Rev 15(4):603-626. https://doi.org/10.5465/AMR.1990.4310825

Gillespie K, Riddle L, Sayre E, Sturges D (1999) Diaspora interest in homeland investment. J Int Bus Stud 30(3):623-634. https://doi.org/10.1057/palgrave.jibs.8490087

Granovetter MS (1973) Granovetter - the strength of weak ties. pdf. Am J Soc 78(6):1360-1380

Granovetter M (1985a) Economic action and social structure: the problem of embeddedness mark granovetter. Am J Sociol 91(3):481-510. https://doi.org/10.1086/228311

Granovetter M (1985b) The problem of embeddedness. Am J Soc Am J Soc This 91(3):481-510. https://doi. org/Doi. https://doi.org/10.1086/228311

Hill TL, Mudambi R (2010) Far from Silicon Valley: how emerging economies are re-shaping our understanding of global entrepreneurship. J Int Manag 16(4):321-327. https://doi.org/10.1016/j. intman.2010.09.003

Johanson J, Mattsson L-G (2015) Internationalisation in industrial systems - a network approach. In: Knowledge, networks and power. Palgrave Macmillan UK, London, pp 111-132. https://doi. org/10.1057/9781137508829_5

Johanson J, Vahlne J-E (2009) The Uppsala internationalization process model revisited: from liability of foreignness to liability of outsidership. J Int Bus Stud 40(9):1411-1431. https://doi.org/10.1057 jibs.2009.24

Jones MV, Coviello NE (2005) Internationalisation: conceptualising an entrepreneurial process of behaviour in time. J Int Bus Stud 36(3):284-303. https://doi.org/10.1057/palgrave.jibs.8400138

Jones MV, Coviello N, Tang YK (2011) International entrepreneurship research (1989-2009): a domain ontology and thematic analysis. J Bus Ventur 26(6):632-659. https://doi.org/10.1016/j. jbusvent.2011.04.001

Jones T, Ram M, Edwards P, Kiselinchev A, Muchenje L (2014) Mixed embeddedness and new migrant enterprise in the UK. Entrep Reg Dev 26(5-6):500-520. https://doi.org/10.1080/08985626.2014.950697

Kloosterman RC (2010) Matching opportunities with resources: a framework for analysing (migrant) entrepreneurship from a mixed embeddedness perspective. Entrep Reg Dev 22(1):25-45. https://doi. org/10.1080/08985620903220488

Kloosterman R, Rath J (2001) Immigrant entrepreneurs in advanced economies: mixed embeddedness further explored. J Ethn Migr Stud 27(2):189-201. https://doi.org/10.1080/13691830020041561

Kotabe M, Mudambi R (2009) Global sourcing and value creation: opportunities and challenges. J Int Manag 15(2):121-125. https://doi.org/10.1016/j.intman.2009.03.001

Mahroum S (2000) Highly skilled globetrotters: mapping the international migration of human capital. R D Manag 30(1):23-32. https://doi.org/10.1111/1467-9310.00154

Mainela T, Puhakka V, Servais P (2014) The concept of international opportunity in international entrepreneurship: a review and a research agenda. Int J Manag Rev 16(1):105-129. https://doi.org/10.1111 /ijmr. 12011

Marschan-Piekkari R, Welch C (2004) Qualitative research methods in international business: The state of the art. In: Marschan-Piekkari R \& Welch CJ (eds) Handbook of qualitative research methods for international business, Cheltenham: Edward Elgar, p 5-24

Masurel E, Nijkamp P, Tastan M, Vindigni G (2002) Motivations and performance conditions for ethnic entrepreneurship. Growth Change 33(2):238-260. https://doi.org/10.1111/0017-4815.00189

Newland K and Tanaka H (2010) Mobilizing diaspora entrepreneurship for development. Migration Policy Institute, Washington, DC

Nijkamp P, Sahin M, Baycan-levent T (2010) Migrant entrepreneurship and new urban economic opportunities: identification of critical success factors by means of qualitative pattern recognition analysis. Tijdschr Econ Soc Geogr 101(4):371-391. https://doi.org/10.1111/j.1467-9663.2009.00546.x

Nkongolo-Bakenda JM, Chrysostome EV (2013) Engaging diasporas as international entrepreneurs in developing countries: in search of determinants. J Int Entrep 11(1):30-64. https://doi.org/10.1007 /s10843-012-0098-1 
Oviatt BM, McDougall PP (2005) Defining international entrepreneurship and modeling the speed of internationalization. Entrep Theory Pract 29(5):537-554. https://doi.org/10.1111/j.15406520.2005.00097.x

Powell JL, Steel R (2011) Revisiting Appadurai: globalizing scapes in a global world the pervasiveness of economic and cultural power. Int J Innov Interdiscip Res 1:74-80

Price M, Chacko E (2009) The mixed embeddedness of ethnic entrepreneurs in a new immigrant gateway. J Immigrant Refug Stud 7(3):328-346. https://doi.org/10.1080/15562940903150105

Ram M, Theodorakopoulos N, Jones T (2008) Forms of capital, mixed embeddedness and Somali enterprise. Work Employ Soc 22(3):427-446. https://doi.org/10.1177/0950017008093479

Rana MB, Elo M (2017) Transnational diaspora and civil society actors driving MNE internationalisation: the case of Grameenphone in Bangladesh. J Int Manag 23(1):87-106. https://doi.org/10.1016/j. intman.2016.11.005

Rath J, Kloosterman R (2000) Outsiders' business: a critical review of research on immigrant entrepreneurship. Int Migr Rev 34(3):657-681. https://doi.org/10.2307/2675940

Riddle L, Brinkerhoff J (2011) Diaspora entrepreneurs as institutional change agents: the case of Thamel.com. Int Bus Rev 20(6):670-680. https://doi.org/10.1016/j.ibusrev.2011.02.013

Riddle L, Hrivnak GA, Nielsen TM (2010) Transnational diaspora entrepreneurship in emerging markets: bridging institutional divides. J Int Manag 16(4):398-411. https://doi.org/10.1016/j.intman.2010.09.009

Sandberg S, Immonen R, Kok S (2017) 'Refugee entrepreneurship: taking a social network view on immigrants with refugee backgrounds starting transnational businesses in Sweden', Int. J. Entrepreneurship and Small Business, (in press)

Sheffer G (2003) Diaspora politics: At home abroad. Diaspora Politics: At Home Abroad. https://doi. org/10.1017/CBO9780511499432

Solano G (2016) Multifocal entrepreneurial practices: the case of Moroccan import/export businesses in Milan. Int J Entrep Small Bus 29(2):176. https://doi.org/10.1504/IJESB.2016.078698

Stahl GK, Tung RL (2015) Towards a more balanced treatment of culture in international business studies: the need for positive cross-cultural scholarship. J Int Bus Stud 46(4):391-414. https://doi.org/10.1057 /jibs.2014.68

Terjesen S, Elam A (2009) Transnational entrepreneurs' venture internationalization strategies: a practice theory approach. Enterp Theory Pract 33(5):1093-1120. https://doi.org/10.1111/j.15406520.2009.00336.x

Tölölyan K (2007) The contemporary discourse of diaspora studies. Comp Stud South Asia, Africa, Middle East 27:647-655. https://doi.org/10.1215/1089201x-2007-040

Tung RL (2008) Brain circulation, diaspora, and international competitiveness. Eur Manag J 26(5):298-304

Tung R (2018) Prologue- Voyages of self-discovery: a reflection on four decades of research on expatriation and cross-cultural interactions, in Verbeke, A., Puck, J. \& van Tulder, R. (eds) Distance in International Business: Concept, Cost and Value, Progress in International Business Research, Emerald Publishing, Volume 12:1-15

Turunen H, Nummela N (2016) Internationalisation at home: the internationalisation of location-bound service SMEs. J Int Entrep 15:1-19. https://doi.org/10.1007/s10843-016-0167-y

Urbano D, Toledano N, Ribeiro-Soriano D (2011) Socio-cultural factors and transnational entrepreneurship: a multiple case study in Spain. Int Small Bus J 29(2):119-134. https://doi.org/10.1177/0266242610391934

Vance CM, McNulty Y, Paik Y, D’Mello J (2016) The expat-preneur: conceptualizing a growing international career phenomenon. J Glob Mob: Home Expatriate Manage Res 4(2):202-224. https://oi.org/10.1108 /JGM-11-2015-0055

Vance CM, Larrieu RJ, Bergin R, Mercado J, Richmond J, Walden M, Reeser C (2017) A field exploration of the "expat-preneur" phenomenon. Glob Bus Organ Excell 36(6):34-43. https://doi.org/10.1002 /joe. 21812

Vertovec S (2004) Migrant \{transnationalism\} and \{modes\} of \{transformation\}. Int Migr Rev 38(3):9701001. https://doi.org/10.1111/j.1747-7379.2004.tb00226.x

Welch LS, Luostarinen RK (1993). Inward-outward connections in internationalization. J Int Mark 1(1):44-56

Welter F (2011) Contextualizing entrepreneurship-conceptual challenges and ways forward. Entrep Theory Pract 35(1):165-184. https://doi.org/10.1111/j.1540-6520.2010.00427.x

Wiklund J, Davidsson P, Audretsch DB, Karlsson C (2011) The future of entrepreneurship research. Enterp Theory Pract 35(1):1-9. https://doi.org/10.1111/j.1540-6520.2010.00420.x

Wright R and Ellis M (2016) Perspectives on migration theory: geography (pp. 11-30). https://doi.org/10.1007 /978-94-017-7282-2_2

Zahra SA, Wright M, Abdelgawad SG (2014) Contextualization and the advancement of entrepreneurship research. Int Small Bus J 32(5):479-500. https://doi.org/10.1177/0266242613519807 